\title{
Content Uniformity
}

National Cancer Institute

\section{Source}

National Cancer Institute. Content Uniformity. NCI Thesaurus. Code C134250.

An assessment of the quality of the sameness of the contents of a substance. 